\title{
Drainage Channels to Control Flooding and Road Damage
}

\author{
Alik Ansyori Alamsyah* \\ Department of Civil Engineering, Faculty of Engineering, University of Muhammadiyah Malang, Jl. Raya \\ Tlogomas 246, Malang, East Java, Indonesia \\ * Corresponding author: alik_a@umm.ac.id
}

\section{ARTICLE INFO}

Article history

Received May 2, 2020

Revised May 26, 2020

Accepted May 26, 2020

Available Online May 31, 2020

Keywords

Environmental Awareness

Drainage Treatment

\begin{abstract}
The purpose of this program is to motivate the community to build and control the drainage channels. Ngenep Village often experiences floods caused by high rainfall and extreme differences in the original land surface. Seeing this condition, an assistance program should be carried out to realize the hopes of the people of Ngenep Village to have a drainage channel that can hold rainwater. This program is carried out on the residents of Ngenep Village, Karangploso Malang with the hope of increasing the accessibility of the Ngenep village community and other villages that often pass the road. This program was carried out with data collection and data processing that included observations and interviews with the people of Ngenep Village. It was found that the people of Ngenep Village lacked awareness of their environment and cleanliness, this was compounded by the lack of role of the Village apparatus as Modeling or who gave treatments that could set an example for the Ngenep Village Community. The results of the intervention, especially training and outreach to citizens, showed an increase in motivation to change lifestyles from the inattentive to be more attentive to the environment, this is indicated by the start of maintenance and care of the road drainage channels.
\end{abstract}

This is an open access article under the CC-BY-SA license.

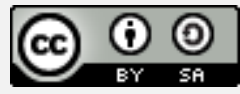

\section{Introduction}

Ngenep is an area located in the North of Karangploso. With a population of around 6,614 people, it is one of the most densely populated villages in the Karangploso area. The majority of the population has farmers' incomes and a majority educated at a junior high school level.

Ngenep is a village that occupies an area that has a extreme contour. So that we need a drainage channel that is adequate to be able to accommodate the overflow of rainwater which is also relatively high. So far, Ngenep often experiences floods caused by high rainfall and is support by extreme differences in the original land surface. 
The floods that have been occurring have also been greatly affected by the very poor drainage channels available in Ngenep Village. So that when it rains, the water that flows from upstream of Ngenep Village flows swiftly to its hill. Poor drainage channel,, the rainwater flow is not accommodated by the existing drainage channels but overflows the streets and the houses of the surrounding population. It is necessary to carry out a mentoring program to realize the demand of the people of Ngenep to have a drainage channel that can accommodate the rainfall. The purpose of this assistance program is how to motivate the community to build a drainage channel while controlling the drainage channel so that vehicles can pass the village road, which has always been flooded in the event of rain, smoothly.

Besides that, in the absence of flooding in Ngenep, it can increase the planned life of existing pavement roads. From the description in the situation analysis above, it can be formulated the problems faced by the people of Ngenep, namely: Every rainy season, water flowing in the existing drainage channels always overflows the village road pavement, the village road pavement is always damaged during the season raining. There has never been a mentoring program that aims to plan and create drainage channels to prevent flooding in the village of Ngenep, Karangploso.

This program was carried out to eliminate flooding, realized the age of the road pavement plan in Ngenep, provided assistance to the drainage channel development program in Ngenep. It is hoped that this activity can provide motivation and knowledge about the importance of drainage channels to prevent flooding on the main road. It is hoped that the results of the design and planning costs for the construction of road drainage channels will realize the construction of drainage channels in Ngenep. Besides, it can increase the accessibility of vehicles that pass through.

\section{Methods}

This program is carried out on the Ngenep Village who are expected to increase the accessibility of the Ngenep village that often passes the main road. Besides that, this program is also expected to be able to extend the life of the existing road pavement plan, which will be carried out in March 2019 to October 2019.

In this community service program there are several stages of the program, namely: motivating public awareness about the importance of high accessibility, realizing the construction of drainage channels in the main village road, providing assistance after the construction of drainage channels (maintenance of road drainage channels).

To plan flood control in an area, rainfall data are needed that represent the area concerned. In this study the rainfall needed is hourly rainfall obtained from Automatic Rainfall Record (ARR). This rainfall is averaged throughout the area concerned and not rainfall at a certain point. This rainfall is called regional rainfall which is expressed in the form of $\mathrm{mm}$.

Design rainfall is the greatest rainfall that may occur in an area with a certain return period [1], [2]. To determine the amount of rainfall the design needs to be held to choose the frequency distribution. In selecting the frequency distribution used first, the amount of $\mathrm{Cv}, \mathrm{Ck}$, and $\mathrm{Cs}$ calculated from the statistical parameters is calculated. A simple description of the mechanism of rainfall to runoff can form an equation. The concept of mass balance flow by making the input equal to output coupled with storage, which is applied to a simple area. The relationship between water depth and flow shape is an important part of predicting the movement of equations [3]. 
The process of occurrence of runoff depends on the amount of rain falling in a measured area. With the influence of natural reservoirs and infiltration can reduce the amount of peak flow discharge. The form of a runoff and peak discharge is a function of the intensity of rainfall that occurs can be derived from the flow in the area which is assumed to be a simple form.

A complete contour line map of the runway, taxi way, and apron is very useful for the floor plan of the rainwater drainage system [4]. Some trial and error drainage plans may be needed before the most economical system can be chosen.

Planning for runway drainage at airports always uses two types of drainage canals, namely channels above the surface (surface) and channels below the surface (subsurface). The surface channel is used outside the runway safe area which is $\square 55 \mathrm{~m}$ from the runway pavement area. While the subsurface channel is placed in the shoulder area of the runway (shoulder) between the runway and the landing runway (taxiway).

The most common form of cross-section found in the field of flying is the trapezoidal form. Trapezoid-shaped channels have advantages both in terms of hydraulic, trapezoidshaped channels with a relatively small hydraulic radius $(\mathrm{R})$ capable of flowing relatively large discharges. This means that if $\mathrm{R}$ is enlarged, automatically the ability to flow the discharge is also greater when compared to rectangular, rectangular, or triangular crosssections.

The dimensions of the drainage channel section are calculated using a uniform flow formula approach that has properties as inflow, the cross-sectional area, flow velocity, and discharge are always fixed at each cross-section, the maximum speed is limited, and the pair weight must be sufficient to compensate for the above compressive forces [5], [6]

Maximum speeds for the following subcritical flow are recommended: (KP 03, 1986: 39) [7].
- Rocks Foundation $=2 \mathrm{~m} / \mathrm{dt}$
- Concrete Foundation $=3 \mathrm{~m} / \mathrm{dt}$
- Soil Foundation = maximum allowable speed

While the roughness coefficient stricker $\mathrm{k}(\mathrm{m} 1 / 3 / \mathrm{dt})$ recommended use: (KP 03, 1986 : 40)[7]

- Rocks Foundation $=60$

- $\quad$ Concrete Foundation $=70$

- $\quad$ Soil Foundation $\quad=35-45$

For subsurface planning, where the pipeline is filled $2 / 3$ full, in other words the flow inside the pipeline has a depth of $75 \%$ of the pipe diameter to be planned. In planning the flow depth in the pipeline it is highly recommended that the flow that occurs in the channel is free flow because the difference in energy and excessive height between the axes and the height of the water above the axle pipe to account for the pressure that occurs in the pipeline (KP 03 1986: 41) [7].

\section{Results and Discussion}

From the results of data collection, and data processing which includes direct observation and face to face in the form of sharing with all the people of Ngenep, it turns out that the majority of the population of Ngenep hopes for a change in their village related to environmental hygiene and public health issues. In the structured socialization activities, there was a lack of harmony between the community and the government of Ngenep, Karangploso. 
The results of socialization and sharing with the community obtained by the compiler really very surprising, because from the location reviewed it turns out that the rice fields are very close to the flow of the river to get water supply due to poor drainage channels. This is very disturbing to the development of rice planted in the area. This clearly can reduce the productivity of the rice field. During the rainy season, conduct overflows onto the highway, causing damage to the pavement surface of the road.

The training and compilers in this program collaborated with several elements, one of them is a team from Public Works Office Karangploso and staff from the sub-district. The training that had been planned, was really important in changing the mindset of the people. Training related to environmental cleanliness has been attended by elements of the community which include Youth Organization and Woman Society which has made an interesting discussion. This is a new thing for the people of Ngenep. The direct impact of the training was the establishment of communication between water-using farmers to irrigate their fields so that there was no overlap and damage to each other's waterways to the rice fields which at the end would spread to drainage channels alongside the village road. Besides that, people who have rarely done maintenance and cleaning of drainage channels, now routinely carry out the cleaning of channels because, with damage to drainage channels, it will damage roads which will also increase vehicle operating costs.

In this discussion there are no measurable parameters and indicators that indicate a success in this program. Even so in this program it can still be stated quantitatively to declare its success, also attached with several documents that support the level of success of the program.

The motive for success can be increased through training [8]. Actually, the training can be done by an institution or parents. McClelland even concluded the large role of all components in the community to spread the Need of Achievement virus. Parents can begin to instill awareness of the environment and health through fairy tales told to their children that describe a struggle of the character to change the order that starts from his own environment.

Based on application research it is proven that structured training or outreach can increase the motivation of the community in their efforts to make a change in their environment. The training was designed to increase public understanding and awareness of the importance of a clean and healthy environment in their respective regions. Although this also requires a process and time.

Based on the results of this assistance, it can be proven that structured training and outreach can increase motivation to change for the people of Ngenep village, Karangploso District, Malang Regency. This training uses a learning by doing technique model so that the community can appreciate it because they experienced it themselves. It appears that after receiving structured training and outreach the community has a desire or a better plan to change lifestyles that seem unconcerned with their environment, including the impact of damage to the drainage channel. Once again, despite this success, it turned out that the community as a whole in the village, so that in the future it would still be necessary to conduct a structured training and outreach to achieve the desired target. 


\section{References}

[1] Basuki, I. Winarsih, and N. L. Adhyani, "Analisis Periode Ulang Hujan Maksimum dengan Berbagai Metode (Return Period Analyze Maximum Rainfall With Three Method)," Agromet, vol. 23, no. 2, p. 76, 2009, doi: 10.29244/j.agromet.23.2.76-92.

[2] M. Bisri and M. J. Ismoyo, "Kabupaten Gresik Berbasis Konservasi," vol. 3, pp. 102-111, 2012.

[3] D. Stephenson, "Energy dissipation down stepped spillways," Int. Water Power Dam Constr., vol. 9, no. 43, pp. 27-30, 1991.

[4] B. S. Nasional, "Tata cara perencanaan sistem plambing," (BSN), Badan Standar Nas., no. SNI 037065-2005, p. 23, 2005.

[5] M. G. Heka, "Pabrik PT. Sinar Alam Permai Kabupaten Banyuasin," vol. 2, no. 3, pp. 560-564, 2014.

[6] D. S. Krisnayanti et al., "Perencanaan drainase kota Seba," J. Tek. Sipil, vol. VI, no. 1, pp. 89-102, 2017.

[7] D. SDA, "Standar Perencanaan Irigasi," pp. 1-197, 2013.

[8] D. Mc Clelland, Memacu Masyarakat Berprestasi. Jakarta: Intermedia, 1987. 